\title{
SEED DORMANCY BREAKING OF AN ENDANGERED MEDICINAL TREE SPECIES (TAXUS BACCATA L.) USING EMBRYO CULTURE
}

\author{
Mohamed BEKHOUCHE ${ }^{1}$, Abdelkader MORSLI ${ }^{1, *}$, Majda KHELIFI-SLAOUI ${ }^{1}$, \\ Roukia BENYAMMI ${ }^{1}$, Hayette ZAOUT ${ }^{1}$, Lakhdar KHELIFI ${ }^{1}$ \\ *E-mail: a.morsli@ensa.dz
}

Received: Jan. 12, 2021. Revised: Feb. 24, 20201 Accepted: Mar. 19, 2021. Published online: Mar. 31, 2021

\begin{abstract}
Natural regeneration of Taxus baccata $\mathrm{L}$. is constrained due to the depth of seed dormancy requirements (often taking two or more years) and low seed germination. Further, the conventional method of vegetative propagation by cuttings is associated with difficulties in rooting. Hence, for the first time, this study describes an efficient and reproducible in vitro protocol for breaking the dormancy of seeds from the endangered forest tree T. baccata L. via zygotic embryo culture. Embryos isolated from $100 \%$ sterile seeds were cultured on DCR medium that contains sucrose $(30 \mathrm{~g} / \mathrm{l})$, agar $(8 \mathrm{~g} / 1)$, and activated charcoal (5 g/l), fortified with different concentrations of Plant Growth Regulators (PGRs), and held at a temperature of $25 \pm 2{ }^{\circ} \mathrm{C}$ in a growth room. The results revealed that the in vitro embryo germination percentage was mostly affected by gibberellic acid (GA3) and thidiazuron (TDZ). Among the nine treatments, the treatments with $0.5 \mathrm{mg} / 1 \mathrm{TDZ}$ and $1 \mathrm{mg} / \mathrm{l} \mathrm{GA} 3$ showed
\end{abstract}

the highest germination $(100 \%)$, while the other treatments all increased the germination percentages significantly compared to the control $(37.5 \%)$. The $1 / 2$ DCR medium with the addition of 0.1 $\mathrm{mg} / \mathrm{l}$ indole-3-butyric acid (IBA) resulted in the highest rooting ratio (94\%). However, the greatest root and hypocotyl elongation $(59.37 \pm 3.77$ and $62.75 \pm$ $4.43 \mathrm{~mm}$, respectively) occurred when seedlings were cultured on $1 / 2$ DCR medium containing $0.5 \mathrm{mg} / \mathrm{l} \mathrm{BA}$. Plantlets were transplanted into plastic pots containing an autoclaved garden soil, sand, and vermiculite mixture $(1: 1: 1)$ and held at a temperature of $25 \pm 2{ }^{\circ} \mathrm{C}$ in a growth room for 4 weeks before being transplanted into the greenhouse. These results indicated that the protocol developed during the current study will be useful to overcome seed dormancy and for multiplication and conservation of the species T. baccata L.

Keywords: common yew; germination; seedlings; zygotic embryo culture.

\footnotetext{
1 Laboratoire de Ressources Génétiques et Biotechnologies (LRGB), Département de production et amélioration des plantes, Ecole Nationale Supérieure Agronomique (ENSA-ES1603), El Harrach-Algiers, Algeria
} 


\section{INTRODUCTION}

Taxus species, belonging to the family Taxaceae, are small trees or shrubs valued for their medicinal properties (Hao et al., 2015; Romo et al., 2017). There are seven closely related species worldwide (Gegechkori, 2018), including Taxus baccata L., which is the only representative in Algeria. T. baccata L., commonly known as yew, is a gymnosperm shrub or tree with evergreen needle-leaves reaching heights of up to $28 \mathrm{~m}$, frequently with many trunks and pyramidal or rounded canopy (Nasr et al., 2007; Chauhan, 2017). T. baccata L. is a valuable medicinal plant, especially for its taxol (Paclitaxel) content, and an important chemo-therapeutic agent for treating several types of cancer as well as AIDS-related Kaposi's sarcoma (Osuna-Torres et al., 2015). Besides, this species is also valued for its hardwood, which is used for musical instruments and furniture making (Lanker et al., 2010; Romo et al., 2017).

Natural regeneration of common yew is constrained mainly due to the depth of seed dormancy requirements (often taking two or more years) and low seed germination (Liao et al., 2006; Hosseini Tafreshi et al., 2011). According to Shakarishvili (2009), special pretreatment is necessary for seed dormancy breaking in Taxus species. Devillez (1978) showed that the seeds of $T$. baccata cannot assuredly germinate if they have not been subjected to the succession of a warm and a cold period. According to the same author, the best method is to place the seeds at $15-25^{\circ} \mathrm{C}$ for 6 months, then stratify them at $5^{\circ} \mathrm{C}$ for 3 months, and finally incubate them for about 20 days at $10-20^{\circ} \mathrm{C}$. Suszka (1985) recommended that $T$. baccata seeds should be placed at $15-20^{\circ} \mathrm{C}$ for 6 to 6.5 months, then stratified at $3{ }^{\circ} \mathrm{C}$ for 4 to 4.5 months, and finally incubated for about two weeks at $20^{\circ} \mathrm{C}$. However, using these stratification techniques will require, depending on the case, 9.5 to 12 months to obtain all possible germinations.

Previous studies have been carried out on dormancy breaking in T. baccata L. Most of them concern in vitro zygotic embryo culture (Liao et al., 2006; Zarek, 2007; Nasr et al., 2007). They found that the dormancy of T. baccata embryos was produced by two things: the existence of endogenous inhibitors (abscisic acid, ABA) and the immaturity of zygotic embryos. The removal of inhibitors requires the soaking of seeds in water and use of gibberellins (Ibrahim et al., 2016). The immaturity could be overcome by maintaining isolated embryos on a proper medium under in vitro conditions (Liao et al., 2006). Nonetheless, the use of these protocols was insufficient to obtain a germination ratio higher than $62 \%$ in the best case (Liao et al., 2006; Nasr et al., 2007).

On the other hand, the species faces the threat of extinction because of the strong demand for both taxol and wood production and the difficulty of propagation (Lanker et al., 2010; 
Peragón et al., 2015; Romo et al., 2017). Common yew is now cataloged as an endangered species in Algeria and protected by Executive Presidential Decree No. 12-03 of 1 April 2012 in the list of uncultivated plant species protected.

In view of the above, there is an urgent need to develop a protocol for multiplication and conservation of T. baccata. Plant embryo culture is a valuable tool for overcoming the difficulties encountered in propagation of plants through conventional methods (Kagithoju et al., 2013; Yurievna et al., 2019). Hosseini Tafreshi et al. (2011) considered in vitro embryo culture of $T$. baccata a successful strategy to overcome dormancy of Taxus seeds and rapidly develop germinated embryos. Thus far, zygotic embryos from certain Taxus species such as T. chinensis,
T. brevifolia, and T. canadensis have been successfully cultured and the plantlets have been obtained (Liao et al., 2006).

The present investigation was undertaken to develop an efficient and reproducible protocol for overcoming seed dormancy and producing plantlets by embryo culture of $T$. baccata $\mathrm{L}$.

\section{MATERIALS AND METHODS}

\section{Germplasm collection}

Red female cones (Fig. 1A) enclosing mature seeds (Fig. 1B) of T. baccata L. were collected during NovemberDecember 2018 at Glacière station (36 $\left.26^{\circ} 0215 \mathrm{~N}-2^{\circ} 52^{\prime} 3701 \mathrm{E}\right)$ from Chrea National Park, Blida Province, in the North West of Algeria. After removing red arils, the seeds were carefully washed with running water, dried at room temperature, and then kept refrigerated at $4^{\circ} \mathrm{C}$.
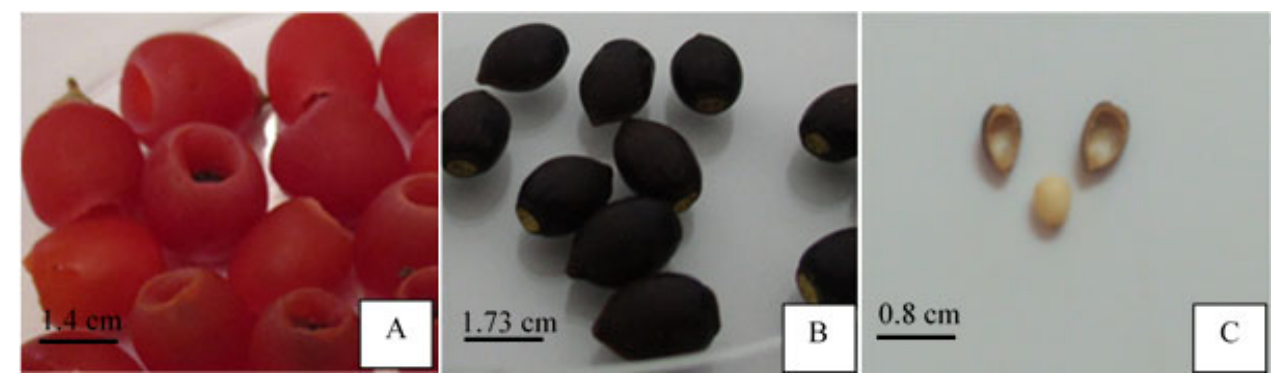

Figure 1 - Seeds of T. baccata $L$.

(A) Red female cones, (B) mature seeds, and (C) scarified seed

\section{Seed germination test}

To determine a baseline and identify whether seeds of $T$. baccata L. were dormant, a germination test was performed in the laboratory under controlled conditions. The scarified seeds (Fig. 1C) were disinfected and inoculated on DCR medium (Gupta and Durzan, 1985), enriched with $5 \mathrm{~g} / \mathrm{l}$ activated charcoal, $8 \mathrm{~g} / 1$ agar, and $30 \mathrm{~g} / 1$ sucrose, and held at a temperature of $25 \pm 2{ }^{\circ} \mathrm{C}$ in a chamber room for 6 months.

\section{Seed sterilization and zygotic embryo isolation}

The seeds were husked before surface disinfection for 30 seconds in $70 \%$ ethanol, rinsed twice in sterile water, 


\section{BEKHOUCHE, A. MORSLI, M. KHELIFI-SLAOUI, R. BENYAMMI, H. ZAOUT, L. KHELIFI}

soaked for $10 \mathrm{~min}$ in $12^{\circ} \mathrm{C}$ sodium hypochlorite, and then rinsed three times in sterile water to completely remove the sterilization agent. The zygotic embryos were excised aseptically from the surrounding megagametophyte by using fine forceps and a scalpel and were then transferred onto the culture medium prepared previously (Fig. 2a).

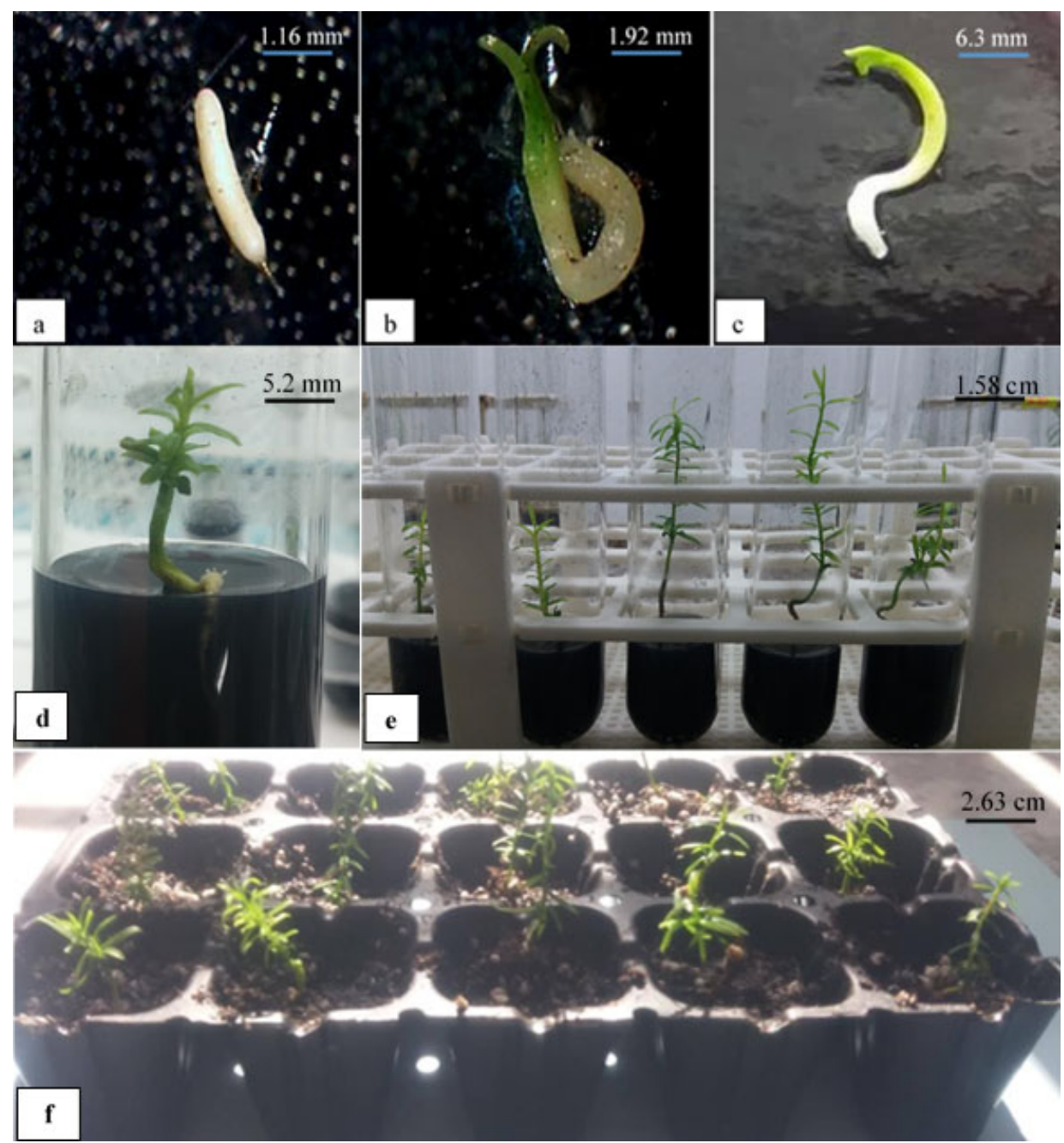

Figure 2 - Zygotic embryo culture and establishment of plantlets of $T$. baccata L.: (a) Zygotic embryo excised from the seed; (b) Separation of the cotyledons and greening of the apical pole; (c) Radical elongation after 21 days of inoculation; (d)

Seedling with leaves and primary root after 11 weeks of inoculation on $1 / 2$ DCR containing $20 \mathrm{~g} / \mathrm{L}$ sucrose supplemented with $0.5 \mathrm{mg} / \mathrm{L}$ BA; (e) Plantlet development on $1 / 2$ DCR containing $20 \mathrm{~g} / \mathrm{L}$ sucrose supplemented with $0.5 \mathrm{mg} / \mathrm{L}$ BA after 16 weeks of incubation; (f) Acclimatization of plants in small pots containing garden soil, sand, and vermiculite $(1: 1: 1)$ 


\section{In vitro culture media and conditions}

As Salaj et al. (2019) found that DCR medium (Gupta and Durzan, 1985) was a better nutrient medium for conifer tree embryo culture. In the present study, DCR medium was used as a basal medium for embryo germination. All media contained $5 \mathrm{~g} / \mathrm{l}$ activated charcoal, $8 \mathrm{~g} / \mathrm{l}$ agar, and $30 \mathrm{~g} / \mathrm{l}$ sucrose. The $\mathrm{pH}$ of all media was adjusted to between 0.56 and 0.58 and the media were then autoclaved at $121^{\circ} \mathrm{C}$ for $20 \mathrm{~min}$. Embryo cultures were kept in the chamber room at $25 \pm 2{ }^{\circ} \mathrm{C}$ in darkness for 15 days, followed by $16 \mathrm{~h}$ light and $8 \mathrm{~h}$ dark.

\section{Plant growth regulators}

The plant growth regulators (PGRs) used in this study were gibberellic acid (GA3), N-Phenyl-N'-1,2,3-thidiazol-5ylurea (TDZ), and 6-benzylaminopurine (BA) in concentrations of $0.5,1$, and $5 \mathrm{mg} / \mathrm{l}$ each. The treatments were repeated five times at the rate of 20 embryos for each treatment, and the control corresponds to the untreated seeds. All the plant growth regulators were obtained from Biochem Chemopharma (France) and prepared using water under alkaline conditions.

\section{In vitro root development and plantlet establishment}

Seedlings with two cotyledons at 3 to 4 weeks old were transferred into $22 \mathrm{~mm} \times 200 \mathrm{~mm}$ test tubes containing $15 \mathrm{ml}$ of half-strength DCR medium (1/2DCR), $20 \mathrm{~g} / 1$ sucrose, $7.5 \mathrm{~g} / 1$ agar and $5.5 \mathrm{~g} / 1$ activated charcoal, supplemented with $0.1 \mathrm{mg} / 1$ naphthalene acetic acid (NAA), $0.1 \mathrm{mg} / 1$ indole-3-butyric acid (IBA), or $0.5 \mathrm{mg} / \mathrm{l}$ 6-benzylaminopurine (BA), and incubated at a temperature of $25 \pm 2^{\circ} \mathrm{C}$ with a photoperiod of $16 \mathrm{~h}$ light $/ 8 \mathrm{~h}$ dark. After 16 weeks, the plantlets were gently removed from the agar, placed individually in small pots containing sterilized garden soil, sand, and vermiculite (1:1:1), and covered with transparent polyethylene bags with small holes to increase the atmospheric exchange. All the plantlets were held at a temperature of $25 \pm 2^{\circ} \mathrm{C}$ for 1 month before being transferred to the greenhouse.

\section{Statistical analysis}

The data were expressed as means of three replicate determinations \pm standard deviation (SD). The data on zygotic embryo germination were evaluated after three weeks of culture. Each experiment was repeated at least five times and each treatment consisted of 20 embryos. The differences were considered to be significant at $p<0.05$. All statistical analyses were performed with SPSS version 19.0.

\section{RESULTS}

\section{Germination of seeds}

After 6 months of culture on DCR nutriment medium, no seedlings were obtained from the scarified seeds (without seed coats). These results indicate that the presence of the hard and impermeable seed coat is not the main cause of the dormancy of T. baccata seeds (Ibrahim et al., 2016). This correlates with the observations of Liao et al. (2006) and Zarek (2007), who found that the megagametophyte of Taxus seeds contained endogenous inhibitors such as ABA, which makes germination impossible.

\section{Isolated zygotic embryo germination}

To allow zygotic embryo isolation, the seeds of yew must be swollen; if not, the zygotic embryo 
cannot be separated from the surrounding tissues. In this study, preliminary experiments showed that putting the embryo on the DCR culture medium along with certain megagametophyte residues independently of the medium composition produced negative results. These findings are similar to the findings of Flores and Sgrignoli 1991, who tried to culture T. baccata embryos together with their embryo sacks.

Table 1 - Effect of various plant growth regulators on zygotic embryo germination of $\mathrm{T}$. baccata $\mathrm{L}$. after 21 days of in vitro culturing

\begin{tabular}{llll}
\hline $\begin{array}{l}\text { Plant growth } \\
\text { regulators }\end{array}$ & $\begin{array}{l}\text { Concentration } \\
\text { (mg/l) }\end{array}$ & $\begin{array}{l}\text { Percentage } \\
\text { germination of } \\
\text { embryos }(\%)\end{array}$ & $\begin{array}{l}\text { Embryo length } \\
(\mathbf{m m})\end{array}$ \\
\hline \multirow{2}{*}{ TDZ } & 0.5 & $100 \mathrm{a}$ & $5.41 \pm 0.76 \mathrm{c}$ \\
\cline { 2 - 4 } & 1 & $90 \mathrm{ab}$ & $8.86 \pm 0.74 \mathrm{~b}$ \\
\cline { 2 - 4 } & 5 & $70 \mathrm{~b}$ & $5.52 \pm 0.41 \mathrm{c}$ \\
\hline \multirow{2}{*}{ GA3 } & 0.5 & $95 \mathrm{a}$ & $9.66 \pm 0.72 \mathrm{ab}$ \\
\hline \multirow{2}{*}{ BA } & 1 & $100 \mathrm{a}$ & $12.07 \pm 0.45 \mathrm{a}$ \\
\cline { 2 - 4 } & 5 & $55 \mathrm{c}$ & $4.44 \pm 0.5 \mathrm{~d}$ \\
\hline PGR-free medium & - & $75 \mathrm{~b}$ & $13.33 \pm 0.28 \mathrm{a}$ \\
\hline & 1 & $75 \mathrm{~b}$ & $8.37 \pm 0.82 \mathrm{~b}$ \\
\hline
\end{tabular}

GA3: gibberellic acid; TDZ: N-phenyl-N'-1,2,3-thidiazol-5-ylurea; BA: 6-benzylaminopurine.

The values are presented as the mean of three replicates \pm the standard deviation.

The data marked with different letters share significance at $p<0.05$ (based on the LSD test).

According to previous studies, the embryo in $T$. baccata seeds is surrounded by tissues containing endogenous inhibitors like ABA, making germination impossible. Only embryos which are removed from the surrounding megagametophyte and placed on a suitable medium will germinate (Zarek, 2007; Ibrahim et al., 2016).

\section{Effect of plant growth regulators} (PGRs) on germination percentage

To determine the most efficient PGRs for embryo germination in T. baccata, the zygotic embryos were cultured on DCR medium that contains $30 \mathrm{~g} / 1$ sucrose, $8 \mathrm{~g} / \mathrm{l}$ agar,
$5 \mathrm{~g} / \mathrm{l}$ activated charcoal, and fortified with different concentrations of PGRs.

The germination pattern was identical in all treatments. The first visible change observed was the swelling of the embryos (Fig. 2a), which results in a large greening of the apical pole followed by the separation of the cotyledons from each other (Fig. 2b), and finally the growth of the radicle (Fig. 2c). Afterwards, further development of the seedlings continued until healthy plantlets were obtained (Fig. 2f).

The results in Table 1 show that GA3 and TDZ have the most influence 
on the germination percentage of embryos. However, the greatest seedling length $(13.33 \pm 0.28 \mathrm{~mm})$ was produced at $0.5 \mathrm{mg} / \mathrm{L} \mathrm{BA}$.

Among the nine treatments, the treatments with $0.5 \mathrm{mg} / 1 \mathrm{TDZ}$ and $1 \mathrm{mg} / \mathrm{l}$ GA3 showed the highest germination $(100 \%)$, while the other treatments all increased the germination percentages significantly compared to the control $(37.5 \%)$.

The effects of GA3 (1 to $2 \mathrm{mg} / \mathrm{l}$ ) and BA $(0.5$ to $2 \mathrm{mg} / \mathrm{l})$ on the germination of $T$. baccata zygotic embryos were investigated by Liao et al. (2006), who found increased germination as compared to untreated embryos. However, the use of this method was insufficient to obtain a germination ratio higher than $62 \%$ in the best case. The results of our investigation are superior to those mentioned above. As a result, it confirms the efficiency of the protocol adopted for breaking the dormancy of seeds from T. baccata.

Plant growth regulators including phytohormones are found to play an important role in seed and embryo germination (Nikolić et al., 2006; Ghosh et al., 2018). The stimulating effects of plant growth regulators, including thidiazuron (TDZ) and 6-benzylaminopurine, on seed germination have been reported in many plants (Tar et al., 2018; Kim et al., 2019). More recently, it has been shown that GA3 is extremely important for seed and embryo germination. Gibberellins are known as growth-promoting hormones which are involved in several processes during plant development such as dormancy release, seed germination, seedling growth, and root proliferation (Vishal and Kumar, 2018). In this context, the results of our investigation are in accordance with those mentioned above, which reported that plant growth regulators such as GA3, TDZ, and BA significantly stimulate the zygotic embryo germination.

Very few studies have been conducted to evaluate the effect of plant growth regulators on germination of $T$. baccata embryos. For example, Zarek (2007) and Ibrahim et al. (2016) suggested that the dormancy of $T$. baccata embryos was induced by two effects: the immaturity of zygotic embryos and the existence of internal inhibitors (ABA). The immaturity could be overcome by maintaining isolated embryos on a proper medium under in vitro conditions. To remove inhibitors, it is necessary to add GA3 or wash out inhibitors (ABA) by leaching in running tap water for 7 days. However, the use of these methods was insufficient to obtain a germination ratio higher than $84 \%$ in the best case.

\section{In vitro root development and establishment of plantlets}

For in vitro root development, seedlings with two cotyledons at 3 to 4 weeks old were transferred into $1 / 2$ DCR medium supplemented with 5 $\mathrm{g} / 1$ activated charcoal, $7.5 \mathrm{~g} / 1$ agar, and $20 \mathrm{~g} / 1$ sucrose and fortified with $0.1 \mathrm{mg} / 1 \mathrm{NAA}$ or $0.1 \mathrm{mg} / 1 \mathrm{IBA}$ individually (Table 2). IBA applications induced more rooting 
than NAA and BA. The $1 / 2$ DCR medium supplemented with $0.1 \mathrm{mg} / 1$ IBA resulted in the highest rooting ratio $(94 \%)$. However, the greatest root and hypocotyl elongations $(59.37$ \pm 3.77 and $62.75 \pm 4.43 \mathrm{~mm}$, respectively) occurred when seedlings were cultured on $1 / 2$ DCR medium containing $0.5 \mathrm{mg} / 1 \mathrm{BA}$ (Table 2)

Table 2 - Effect of plant growth regulators on root development and hypocotyl length

\begin{tabular}{llll}
\hline $\begin{array}{l}\text { Plant growth } \\
\text { regulators }\end{array}$ & $\begin{array}{l}\text { Rooting } \\
\text { percentage } \\
(\%)\end{array}$ & $\begin{array}{l}\text { Root length } \\
(\mathbf{m m})\end{array}$ & $\begin{array}{l}\text { Hypocotyl length } \\
(\mathbf{m m})\end{array}$ \\
\hline $\mathbf{0 . 1} \mathbf{~ m g / l ~ I B A}$ & $94.73 a$ & $58.00 \pm 5.14 \mathrm{a}$ & $20.31 \pm 1.85 \mathrm{c}$ \\
\hline $\mathbf{0 . 1} \mathbf{~ m g} / \mathrm{l} \mathrm{NAA}$ & $75.00 \mathrm{c}$ & $32.00 \pm 2.16 \mathrm{~b}$ & $20.66 \pm 1.63 \mathrm{c}$ \\
\hline $\mathbf{0 . 5} \mathbf{~ m g} / \mathrm{l} \mathrm{BA}$ & $72.22 \mathrm{c}$ & $59.37 \pm 3.77 \mathrm{a}$ & $62.75 \pm 4.43 \mathrm{a}$ \\
\hline PGR-free medium & $84.21 \mathrm{~b}$ & $32.83 \pm 2.84 \mathrm{~b}$ & $48.5 \pm 4.42 \mathrm{~b}$ \\
\hline
\end{tabular}

NAA: naphthalene acetic acid; IBA: indole-3-butyric acid.

The values are presented as the mean of three replicates \pm the standard deviation.

The data marked with different letters share significance at $p<0.05$ (based on the LSD test).

The induction of rooting is an important step in micropropagation protocols. However, it has often proved difficult, particularly in the case of woody plants (Sharma et al., 2017). Use of auxins such as IBA and NAA for the in vitro rooting stage has also been reported by many other types of research (Peña-Baracaldo et al., 2018; Arab et al., 2018); in a study on Prunus, the highest rooting percentage $(100 \%)$ was found on half-strength MS medium (1/2-MS) containing $0.5 \mathrm{mg} / 1 \mathrm{IBA}$ (Sadeghi et al., 2015). IBA has been the most commonly applied auxin for rooting in different woody plants (Henrique et al., 2006; Teixeira da Silva et al., 2019). Furthermore, IBA is more stable and less sensitive to auxin-degrading enzymes (Frick and Strader, 2018).

On the other hand, the stimulatory effect of BA on shoot elongation has been reported in many plants: T. baccata (Liao et al., 2006), Pinus pinaster Ait. (Álvarez et al., 2009), and Pinus tecunumanii (Zanella et al., 2018). Similarly to the present findings, a significant increase in shoot elongation $(90 \mathrm{~mm})$ occurred when shoots of Juniperus phoenicea L. were cultured on $1 / 2$ MS medium $\begin{array}{lllll}\text { containing } & 0.5 & \mathrm{mg} / \mathrm{l} & \mathrm{BA} & (\mathrm{Al}-\end{array}$ Ramamneh et al., 2012).

The results of our investigation are in accordance with those mentioned above which reported that IBA and BA promoted the rooting percentage and shoot elongation in woody plants.

Otherwise, rooted plantlets of $T$. baccata were transplanted into plastic pots containing a mix of autoclaved garden soil, sand, and vermiculite $(1: 1: 1)$ and held at a temperature of $25 \pm 2{ }^{\circ} \mathrm{C}$ in a growth room for 1 month before being transplanted to the greenhouse. 


\section{CONCLUSION}

The seeds of $T$. baccata $\mathrm{L}$. have a complex dormancy. When the seed coats and the megagametophytes were removed, in vitro germination of zygotic embryos was achieved. The findings exposed here report an efficient method for in vitro multiplication of $T$. baccata L. via zygotic embryo culture. Unlike the stratification technique, which requires 9.5 to 12 months to break dormancy in $T$. baccata seeds, this protocol can be applied for rapid propagation and conservation of an endangered forest tree $T$. baccata $\mathrm{L}$.

\section{REFERENCES}

Al-Ramamneh, E.D., Dura, S. \& Daradkeh, N. (2012). Propagation physiology of Juniperus phoenicea L. from Jordan using seeds and in vitro culture techniques: Baseline information for a conservation perspective. African Journal of Biotechnology, 11: 7684-7692, DOI: 10.4314/ajb.v11i30.

Álvarez, J.M., Majada J. \& Ordás, R.J. (2009). An improved micropropagation protocol for maritime pine (Pinus pinaster Ait.) isolated cotyledons. Forestry, 82: 175-184, DOI: 10.1093/forestry/cpn 052.

Arab, M.M., Yadollahi, A., Eftekhari, M., Ahmadi, A., Akbari M., \& Khorami, S. (2018). Modeling and Optimizing a New Culture Medium for In Vitro Rooting of G×N15 Prunus Rootstock using Artificial Neural NetworkGenetic Algorithm. Scientific Reports, 8: 9977, DOI: 10.1038/s4 1598-018-27858-4.
Chauhan, J.M.S. (2017). Conservation of an Endangered Medicinal Plant (Taxus baccata L. Subsp. Wallichiana) of Uttarakhand Himalaya through Embryo Culture. International Journal of Pure \& Applied Bioscience, 5(6): 312-317, DOI: $10.18782 / 2320-7051.5783$.

Devillez, F. (1978). Influence de la température sur la postmaturation et la germination des graines de l'if (Taxus baccata L.). Bulletins de l'Académie Royale de Belgique, 64:203-218, DOI: 10.3406/barb.19 78.58366 .

Erdemoglu, N., Sener, B. \& Choudhary, M.I. (2004). Bioactivity of Lignans from Taxus baccata. Z Naturforsch, C, J. Biosci, 59: 494-498, DOI: 10.1515/znc-2004-7-807.

Frick, E.M. \& Strader, L.C. (2018). Roles for IBA-derived auxin in plant development. J. Exp. Bot, 69: 169177, DOI: $10.1093 / j \mathrm{jb} / \mathrm{er} \times 298$.

Gegechkori, A. (2018). Patterns of distribution and survival of European yew (Taxus baccata L.) in an alpine tree line ecotone in the Greater Caucasus (Georgia). Annals of Agrarian Science, 16: 170-176, DOI: 10.1016/j.aasci.2018.02.006.

Ghosh, A., Igamberdiev, A.U. \& Debnath, S.C. (2018). Thidiazuroninduced somatic embryogenesis and changes of antioxidant properties in tissue cultures of half-high blueberry plants. Scientific Reports, 8: 16978, DOI: 10.1038/s41598-018-35233-6.

Gupta, P.K. \& Durzan, D.J. (1985). Shoot multiplication from mature trees of Douglas-fir (Pseudotsuga menziesii) and sugar pine (Pinus lambertiana). Plant Cell Reports, 4: 177-179, DOI: 10.1007/BF00269282.

Hao DC, Gu X-J \& Xiao PG (2015). 3 Taxus medicinal resources: a comprehensive study. In: Hao DC, Gu X-J, Xiao PG (eds) Medicinal Plants. Woodhead Publishing, pp 97-136, DOI:10.1016/B978-0-08100085-4.00003-7.

Henrique, A., Campinhos, E.N., Ono, E.O. \& Pinho, S.Z. (2006). Effect of 
plant growth regulators in the rooting of Pinus cuttings. Brazilian Archives of Biology and Technology 49: 189196, DOI: 10.1590/S1516-8913200 6000300002.

Hosseini Tafreshi, S.A., Shariati, M., Mofid, M.R. \& Khayam, M. (2011). Rapid germination and development of Taxus baccata L. by in vitro embryo culture and hydroponic growth of seedlings. In Vitro CellDevBiol-Plant 47: 561-568, DOI: 10.1007/s11627-011-9369-0.

Ibrahim, O., Ivanova, V. \& Gercheva, P. (2016). Biotechnological and Conventional Propagation of trees. LAP LAMBERT Academic Publishing, Germany, pp. 1-125.

Kagithoju, S., Godishala, V., Kairamkonda, M. \& Nanna, R.S. (2013). Embryo culture is an efficient way to conserve a medicinally important endangered forest tree species Strychnos potatorum. Journal of Forestry Research, 24: 279-283. DOI: 10.1007/s11676-0130350-0.

Kim, D.H., Kang, K.W., Enkhtaivan, G., Jan, U. \& Sivansen, I. (2019). Impact of activated charcoal, culture medium strength and thidiazuron on non-symbiotic in vitro seed germination of Pecteilis radiata (Thunb.) Raf. South African Journal of Botany, 124: 144-150, DOI: 10.1016/j.sajb.2019.04.015.

Lanker, U., Malik, A.R., Gupta, N.K. \& Butola, J.S. (2010). Natural regeneration status of the endangered medicinal plant, Taxus baccata Hook. F. syn. T. wallichiana, in northwest Himalaya. International Journal of Biodiversity Science, Ecosystem Services \& Management, 6: 20-27, DOI: 10.1080/21513732. 2010.527302.

Lebedev, V. (2019). The rooting of stem cuttings and the stability of uidA gene expression in generative and vegetative progeny of transgenic pear rootstock in the field. Plants,
8(8): 291, DOI: 10.3390/plants808 0291.

Liao, Z., Gong, Y., Pi, Y., (2006). Rapid and efficient in vitro germination of embryos from Taxus media Rehder. Asian.J. Plant. Sci, 5 (1): 139-141, DOI: 10.3923/ajps.2006.139.141.

Nasr, S.H., Modanloo, S., Jalilvand, H. \& Mofidabadi, A.J. (2007). Seed dormancy breakage of recalcitrant yew species (Taxus baccata L.) using embryo culture. J. Biosci, 7(5): 781-785.

Nikolić, R., Mitić, N., Miletić, R. \& Nešković, M. (2006). Effects of Cytokinins on In Vitro Seed Germination and Early Seedling Morphogenesis in Lotus corniculatus L. J. Plant Growth Regul, 25: 187, DOI: 10.1007/s00344-005-0129-4.

Ostrolucká, M.G., Gajdošová, A. \& Libiaková, G. (2007). Protocol for Micropropagation of Quercus spp. In: Jain SM, Häggman $H$ (eds) Protocols for Micropropagation of Woody Trees and Fruits. Springer Netherlands, Dordrecht, pp 85-91.

Osuna-Torres, L., García-Martí, X., Ventura-Zapata, E., López-Upton, J., Zamilpa-Alvarez, A., GonzálezCortazar, M., Herrera-Ruiz, M. \& Tapia-Barrera, N. (2015). Taxus globosa Schltdl. (Mexican yew) and Taxus baccata L. (European yew): intra and interspecies analysis of taxol content and biological activity according to different sources. Forest Systems, 24(3): 45, DOI: 10.5424/fs/2015243-07545.

Peña-Baracaldo, F.J., ChaparroZambrano, H.N., Sierra, A., Rodríguez, J. \& CabezasGutiérrez, M. (2018). Effect of different substrates and auxins on rooting of Leucadendron sp. (Proteaceae). Revista UDCA Actualidad \&amp; Divulgación Científica, 21: 385-393. DOI: 10.31910/rudca.v21.n2.2018.968.

Peragón, J.L.N., Matias, L.F.B. \& Simón, J.P. (2015). Restoration of European yew (Taxus baccata L.) in 


\section{SEED DORMANCY AND PRODUCING PLANTLETS BY EMBRYO CULTURE OF T. BACCATA}

Mediterranean mountains: importance of seedling nursery fertilization and post-planting light levels. Forest Systems, $24: 041$. DOI: $10.5424 /$ fs/2015243-07464.

Romo, A., Iszkuło, G., Seghir Taleb, M., Walas, L. \& Boratyński, A. (2017). Taxus baccata in Morocco: a tree in regression in its southern extreme. Dendrobiology, 78: 63-74, DOI: 10.12657/denbio.078.007.

Sadeghi, F., Yadollahi, A., Kermani, M.J. \& Eftekhari, M. (2015). Optimizing culture media for in vitro proliferation and rooting of Tetra (Prunus empyrean 3) rootstock. Journal of Genetic Engineering and Biotechnology, 13: 19-23, DOI: 10.1016/j.jgeb.2014.12.006.

Salaj,T., Klubicová, K., Matusova, R. \& Salaj, J. (2019). Somatic Embryogenesis in Selected Conifer Trees Pinus nigra Arn. and Abies Hybrids. Front Plant Sci, DOI: 10.3389/fpls.2019.00013.

Shakarishvili, N. (2009). Effect of seed stratification on embryo growth dynamics and dormancy break in Taxus baccata L. Proc. Georgian. Acad. Sci., Biol Ser B 7:3-4.

Sharma, U., Kataria, V. \& Shekhawat, N.S. (2017). In vitro propagation, ex vitro rooting and leaf micromorphology of Bauhinia racemosa Lam.: a leguminous tree with medicinal values. Physiol. Mol. Biol. Plants, 23: 969-977, DOI: 10.1007/s12298-017-0459-2.

Suszka, B. (1985). Conditions for afterripening and germination of seeds and for seedling emergence of
English yew (Taxus baccata L.). Arboretum Kornickie. 30: 285-338.

Tar, K.Y.K., Naing, A.H., Ai, T.N., Chung, M.Y. \& Kim, C.K. (2018). Optimization of factors influencing in vitro immature seed germination in Chionanthus retusus. J. Plant Biotechnol, 45: 347-356, DOI: 10.5010/JPB.2018.45.4.347.

Teixeira da Silva, J.A., Gulyás, A., Magyar-Tábori, K., Wang M.R., Wang, Q.C. \& Dobránszki, J. (2019). In vitro tissue culture of apple and other Malus species: recent advances and applications. Planta, 249:975-1006. https://doi. org/10.1007/ s00425-019-03100-x.

Vishal, B. \& Kumar, P.P. (2018). Regulation of Seed Germination and Abiotic Stresses by Gibberellins and Abscisic Acid. Front Plant Sci, DOI: 10.3389/fpls.2018.00838.

Yurievna NA, Vladimirovna GL, Yurievna NA, Vladimirovna GL (2019). The application of different reproduction techniques for rare species waterlily tulip (Tulipa kaufmanniana Regel.) propagation under ex situ conditions. Ornamental Horticulture 25:450-460, DOI: 10.1590/2447-536x.v25i4.2035.

Zanella LB, Franciscon L, Grunennvaldt RL, et al (2018). Micropropagation of Pinus tecunumanii. Ciência Florestal, 28: 651-660, DOI: $10.5902 / 1980509832058$.

Zarek, M. (2007). A practical method for overcoming the dormancy of Taxus baccata isolated embryos under in vitro conditions. In Vitro Cell. Dev. Biol, 43: 623-630, DOI: 10.1007/s11 627-007-9064-3. 